\title{
Telecomunicações Aeronáuticas: natureza jurídica, regime regulatório e formas de delegação
}

Aeronautical Telecommunications: Juridical Nature, Regulatory Regime and Types of Delegation

\section{RESUMO}

Propósito - Este artigo tem por finalidade analisar a natureza jurídica das telecomunicações aeronáuticas e o poder-dever da União em promover sua delegação.

Metodologia/abordagem/design - Segue-se o método de abordagem descritivo e lógico-indutivo, inquirindo a estruturação serviço no ordenamento pátrio e verificando sua conformação pragmática, para que se possa sugerir um modelo de delegação pertinente.

Resultados - Verifica-se que as telecomunicações aeronáuticas compõem tema muito pouco estudado no âmbito das ciências jurídicas. Enquanto serviço sob a tutela da União, integra elemento da navegação aérea, com intrínseca ligação à segurança aeroportuária, mas com elementos característicos de serviço de telecomunicação (art. 21, XI c/c XII, $c$ da Constituição da República Federativa do Brasil).

Implicações práticas - Considerando o comando legal que permite sua prestação por agentes públicos ou entes privados especializados (art. $47 \mathrm{c} / \mathrm{c} 48$ e parágrafo único do Código Brasileiro de Aeronáutica), tal serviço deveria acompanhar a tendência de despublicização de aeroportos públicos, para ser objeto de delegação autônoma em vasta escala, com a devida definição da correta modalidade (concessão ou autorização).

*Especialista em Regulação da Agência Nacional de Transportes Terrestres cedido à Agência Nacional de Aviação Civil, onde ocupa o cargo de Gerente Técnico de Acompanhamento de Obrigações Contratuais. Bacharel em Direito pela PUC/SP e especialista em Contratos pela COGEAE da PUC/SP e em Direito Tributário pelo IBET. Mestrando em Regulação e Gestão de Negócios do Programa de PósGraduação do Centro de Estudos em Regulação de Mercados da UnB. Contato: fernando.feitosa@anac.gov.br. 
Relevância do texto - Finalmente, espera-se incentivar incursões jurídicas que explorem de maneira mais aprofundada o tema, além de sugerir uma política pública voltada para a privatização das Telecomunicações Aeronáuticas.

Palavras-chave: telecomunicações aeronáuticas, navegação aérea, serviço móvel aeronáutico, regulação, Brasil.

\begin{abstract}
Purpose - This paper examines the juridical nature of aeronautical telecommunications and the Union power to delegate them.

Methodology/approach/design - It follows the method of descriptive and inductive logic, juxtaposing the Brazilian legal framework against its actual implementation toward a proposal of an appropriate delegation model.

Findings - Among the findings, aeronautical telecommunications are scarcely studied in the legal literature. As a public service under the Union's legislative and administrative powers, it represents a keystone element for aeronautical navigation and security, but they are also affected by regulation of the telecommunications sector as telecommunications services (art. 21, XI and XII c, of the Constitution of the Federative Republic of Brazil).

Practical implications - Considering the legal command that allows aeronautical telecommunications provision by public or private specialized entities (art. 47 and art. 48, sole paragraph of the Brazilian Aeronautics Code), such service should follow the trend of privatization of public airports, by being delegated separately from the airport infrastructure on a vast scale, with a clear definition of the appropriate juridical regime (concession or authorization).

Originality/value - This paper encourages legal studies to go deep into the topic of aeronautical telecommunications and suggests a public policy for the nowadays privatization of airports and their ancillary aeronautical telecommunications services.
\end{abstract}

Keywords: aeronautical telecommunications, aeronautical navigation, aeronautical mobile service, regulation, Brazil.

\title{
Introdução
}

As telecomunicações aeronáuticas compõem importante parcela da navegação aérea no mundo. Representa o serviço de apoio e orientação ao transporte aéreo, que é gerido no âmbito das infraestruturas aeroportuárias. 
Dessa forma, o presente estudo busca definir o instituto, além de desvendar suas modalidades e características. Quer-se, ainda, perquirir a natureza jurídica de sua prestação em território brasileiro, com especial atenção à abertura desse mercado para universalização dos serviços de telecomunicações aeronáuticas que permita a ampliação segura do transporte aéreo. In latere, há que se discutir ainda o compartilhamento da infraestrutura de telecomunicações com a aeronáutica brasileira, que se dá em primeiro nível de utilização nos aeroportos.

Assim, cuida-se de serviço de telecomunicações de interesse coletivo, quando apóia o desenvolvimento do serviço público de transporte aéreo de passageiros, de acordo com os termos do art. 175 do Código Brasileiro de Aeronáutica. Esse é o caso do Serviço Móvel Aeronáutico (SMA), destinado à comunicação entre controladores de tráfego e pilotos. Contudo, o SMA também pode representar serviço de interesse restrito, quando oferecido por estações de telecomunicação privadas e por aeródromos particulares na orientação das frotas de aeronaves privadas, quando recebe a denominação de Serviço Limitado Móvel Aeronáutico.

É certo afirmar que tanto para a aviação pública como para a privada, uma expansão da rede de telecomunicações aeronáuticas permitirá a ampliação do tráfego para o transporte aéreo. Com efeito, como se verá abaixo, todo o território nacional é coberto pelo serviço de telecomunicações para a orientação do tráfego, mas com o crescimento do serviço de transporte, pode se admitir que seja necessária um aumento na rede para que se evite a limitação de vôos em razão da insuficiência de seu controle. A partir dessa premissa, faz-se necessário discutir a natureza da gama de serviços que compõem as telecomunicações aeronáuticas e o regime de prestação adequado a cada modalidade, tendo em vista os comandos da Constituição da República Federativa do Brasil (CRFB), do Código Brasileiro de Aeronáutica (CBA) e a Lei Geral de Telecomunicações (LGT).

A atualidade do tema pesquisado se verifica no corrente cenário brasileiro de despublicização da infraestrutura aeroportuária iniciado com a concessão dos aeroportos públicos a partir de 2011. Essa tendência foi asseverada com o lançamento, em 20 de dezembro de 2012, do Programa de Investimentos em Logística: Aeroportos. Esse programa consubstancia-se 
em uma série de ações voltadas a aprimorar a qualidade dos serviços e da infraestrutura aeroportuária, além de ampliar a oferta de transporte aéreo, medidas essas que requerem parelha ampliação nos serviços de telecomunicações aeronáuticas para sua efetividade, tendo em vista o aumento do número de aeronaves que precisarão do serviço.

Logo, o presente artigo se presta, em primeiro momento, a exercitar uma breve incursão histórica sobre as telecomunicações aeronáuticas e a esmiuçar o marco regulatório atual desse serviço, para que se possa entender seu domínio e regime de prestação. Chama a atenção o fato de sua gênese coincidir com a intervenção estatal na Panair do Brasil e o governo da época aproveitar a mão-de-obra que executava o serviço de segurança de vôo para compor a Telecomunicações Aeronáuticas S.A., organizando a primeira experiência pública nessa atividade. Isso significa que a tradição de aeronavegação pública no Brasil tem menos de sessenta anos.

Ato contínuo, busca-se descrever os elementos que integram esse serviço de telecomunicações aeronáuticas, bem como a responsabilidade por sua manutenção e expansão, a fim de se permitir uma mensuração do instituto em termos jurídicos. Em seguida, considerando o arcabouço normativo que cerca o tema, busca-se discutir a natureza e modalidades da outorga desse serviço, além de sua eventual vinculação à concessão da infraestrutura aeroportuária. Alfim, há que se ponderar sobre as modificações que podem ser realizadas no modelo atual em vista do vigente processo de privatização dos aeroportos.

Vale adiantar, por hipótese, que, para que se materialize a política governamental acima anunciada, as telecomunicações aeronáuticas, quando representam serviço de interesse coletivo, por sua natureza, e para cumprimento do princípio da universalização e atualidade do serviço, devem se sujeitar a processo de privatização pontual, no qual sejam previstos significativos investimentos na sua rede. Ademais, enquanto infraestrutura parelha à aeroportuária, auxiliar e necessária ao bom desempenho dos aeródromos brasileiros, por coerência, há que se avaliar o necessário paralelismo que as formas de delegação devem manter no caso. 


\section{Precedentes históricos: a Telecomunicações Aeronáuticas S.A.}

A história das telecomunicações aeronáuticas no Brasil confunde-se com a formação de representativa empresa brasileira de aviação civil: a Panair do Brasil. A empresa, criada inicialmente por Ralph O'Neill, em 17 de março de 1927, sob a alcunha de NYRBA do Brasil, foi incorporada pela Pan American Airways, em 1930, e passou a desempenhar expressivo papel na prestação de serviços de transporte aéreo internacional (Saladino, 2005). Em 1946, a Panair foi a primeira empresa de aviação a atravessar o Atlântico rumo à Europa. ${ }^{1}$ Considerando a nascente indústria de serviços de transporte aéreo e a tímida infraestrutura brasileira de navegação aérea, a empresa teve de manter um estratégico Departamento de Proteção de Vôo e Comunicações.

Com a suspensão das autorizações administrativas para as linhas nacionais e internacionais exploradas pela Panair do Brasil S.A., pelo despacho de 10 de fevereiro de $1964^{2}$, essa mão-de-obra especializada em navegação aeronáutica restou disponível no mercado e sequer seria aproveitada, uma vez que a situação da referida empresa aérea acabou se resolvendo na decretação de sua falência, pelo Decreto-Lei n ${ }^{\circ} 669$, de 3 de julho de 1969.

Aproveitando esse "espólio" da Panair, a União constituiu uma empresa de economia mista denominada Telecomunicações Aeronáuticas Sociedade Anônima - TASA (Silva e Gonçalves, 2008), criada pelo Decreto-Lei $\mathrm{n}^{\circ}$ 107, de 16 de janeiro de 1967 e aprovada e instalada pelo Decreto $\mathrm{n}^{\circ}$ 65.451, de 17 de outubro de 1969. Seu estabelecimento representa o marco inicial para o sistema de proteção de vôo público, que antes ficava sob a responsabilidade de cada companhia aérea (Trigo, 2002). Como a TASA estava submetida ao Ministério da Aeronáutica, houve a migração do regime de prestação do privado para o público, bem como do civil para o militar (primordialmente).

Cabe contextualizar que deflagram-se, nesse período, significativas medidas voltadas para a estruturação da aviação brasileira. Em 1972,

${ }^{1}$ In: http://culturaaeronautica.blogspot.com.br/2009/05/panair-do-brasil.html. Online via WWW, consultado em 5 de janeiro de 2013.

${ }^{2}$ Diário Oficial da União, Seção 1, Parte 1, de 10 de fevereiro de 1965, p. 1708. 
também no âmbito do Ministério da Aeronáutica, cria-se a Diretoria de Eletrônica e Proteção ao Vôo (DEPV), com o escopo de dirigir, orientar, coordenar e controlar as atividades especializadas em eletrônica, comunicações, tráfego aéreo, navegação, meteorologia, fototécnica e cartografia, pelo Decreto ${ }^{\circ}$ 70.627, de 25 de maio daquele ano. Em 2001, o DEPV seria substituído pelo Departamento de Controle do Espaço Aéreo (DECEA), que até os dias de hoje regula, executa e fiscaliza os serviços de telecomunicações aeronáuticas no Brasil.

Além disso, instituiu-se, pela Lei Federal $\mathrm{n}^{\circ}$ 5.862, de 12 de dezembro de 1972, a Empresa Brasileira de Infraestrutura Aeroportuária INFRAERO, tendo por finalidade implantar, administrar, operar e explorar industrial e comercialmente a infraestrutura aeroportuária que lhe for atribuída pelo Ministério da Aeronáutica. Mas a INFRAERO não detinha permissão de receber tarifas sobre comunicações e navegação aérea (art. $6^{\circ}$, I, de sua lei de criação).

Por sua vez, em 1973, pelo Decreto $\mathrm{n}^{\circ}$ 73.160, criam-se o Centro Integrado de Defesa Aérea e de Controle de Tráfico Aéreo (CINDACTA) e os Destacamentos de Proteção ao Vôo, Detecção e Telecomunicações. Esses destacamentos tinham por missão operar e manter os equipamentos de detecção e telecomunicações desse sistema, paralelo ao gerido pela TASA, mas que nele se apoiou. Atualmente existem quatro CINDACTAs para a cobertura do espaço aéreo brasileiro. ${ }^{3}$

A TASA desempenhou suas atribuições até 1995, inclusive com remuneração tarifária específica, como se nota, a título de exemplo, no disposto pelo Decreto-Lei $\mathrm{n}^{\circ} 1.896$, de 17 de dezembro de 1981, pelo Decreto $\mathrm{n}^{\mathrm{o}}$ 86.864, de 21 de janeiro de 1982, quando se autorizou sua incorporação pela INFRAERO, e pelo Decreto $\mathrm{n}^{\circ} 1.691$ de 8 de novembro de 1995. Essencial destacar que esse último decreto evocava escore no artigo 84, incisos IV e VI da Constituição Federal (atribuições do Presidente da República), e o estabelecido no inciso I do artigo 26 da Lei ${ }^{\circ} 9.074$, de 7 de julho de 1995.

${ }^{3}$ In: www.decea.gov.br/unidades. Online via WWW, consultado em 30 de janeiro de 2013. 
Em relação a este apoio legislativo, o comando normativo autoriza à União a promover cisões, fusões, incorporações ou transformações societárias dos concessionários de serviços públicos sob o seu controle direto ou indireto, exceto para os serviços públicos de telecomunicações. Esse elemento denota que ou as telecomunicações aeronáuticas não representavam, na leitura dos elaboradores da norma, serviço de telecomunicações ou simplesmente se assumiu que sua natureza jurídica não era de serviço público. Essa questão, que será também será discutida a seguir, faz crer que, na elaboração da referida norma, a TASA não foi considerada prestadora de serviços públicos de telecomunicações, mas fornecedora de serviço misto, mais afeito ao transporte aéreo que às telecomunicações.

É fato que depois de assumir esse serviço e modificar seu estatuto social e atribuições, a INFRAERO vem desempenhando o serviço de telecomunicações aeronáuticas no âmbito dos aeroportos e em algumas estações esparsas no território nacional, paralelamente ao DECEA, mas não com a mesma cobertura deste.

A partir de 2004, o Decreto ${ }^{\circ} 5.196$ aprovou a estrutura regimental do Comando da Aeronáutica para, entre outras disposições, atribuir ao DECEA a competência para planejar, gerenciar e controlar as atividades relacionadas com controle do espaço aéreo, com a segurança da navegação aérea, com as telecomunicações aeronáuticas e com a tecnologia da informação. É importante ressaltar que essa designação foi mantida com o Decreto $\mathrm{n}^{\circ} 6.834$, de 30 de abril de 2009, no art. 19, I da nova estrutura regimental, inciso este incluído pelo Decreto 7.245, de 2010. Conforme ressalta Pinto (2008), essa medida alocou o DECEA na posição de órgão central do Sistema de Controle do Espaço Aéreo Brasileiro (SISCEAB), destacando-se entre os seus objetivos o de desenvolver, normatizar, operar e manter os meios de telecomunicações aeronáuticas em proveito da Circulação Aérea Geral.

Cabe um breve esclarecimento de ordem operacional para o momento. Tanto a INFRAERO como o DECEA prestam o serviço de telecomunicações aeronáuticas, para aeronaves civis e militares, salvo no caso de movimentação em espaço aéreo restrito ou exercício militar. A diferença está na capilaridade da rede militar, que é mais ampla. 
Por fim, deve-se mencionar que a regulamentação das tarifas de telecomunicações, que estava a cargo do Decreto $\mathrm{n}^{\mathrm{o}} 1.896$, de 17 de dezembro de 1981, passou a ser disciplinada por alterações à Lei $\mathrm{n}^{\circ} 6.009$, de 26 de dezembro de 1973, decorrentes da Medida Provisória $n^{\circ}$ 551, de 22 de novembro de 2011, convertida na Lei $\mathrm{n}^{\circ}$ 12.648, de 17 de maio de 2012. Por esta atualização legislativa, positivou-se a seguinte estrutura de tarifação do serviço:

Art. $8^{\circ}$. A utilização das instalações e serviços destinados a apoiar e tornar segura a navegação aérea, proporcionados pelo Comando da Aeronáutica, está sujeita ao pagamento das seguintes tarifas de navegação aérea:

I - Tarifa de Uso das Comunicações e dos Auxílios à Navegação Aérea em Rota - devida pela utilização do conjunto de instalações e serviços relacionados ao controle dos vôos em rota, de acordo com as normas específicas do Comando da Aeronáutica;

II - Tarifa de Uso das Comunicações e dos Auxílios-Rádio à Navegação Aérea em Área de Controle de Aproximação devida pela utilização do conjunto de instalações e serviços relacionados ao controle de aproximação, de acordo com as normas específicas do Comando da Aeronáutica;

III - Tarifa de Uso das Comunicações e dos Auxílios-Rádio à Navegação Aérea em Área de Controle de Aeródromo devida pela utilização do conjunto de instalações e serviços relacionados ao controle de aeródromo ou aos serviços de informações de vôo de aeródromo, de acordo com as normas específicas do Comando da Aeronáutica.

$\S 1^{\circ}$. Os serviços de que trata o caput poderão, a critério do Comando da Aeronáutica, ser prestados por outros órgãos e entidades públicos e privados.

$\S 2^{\circ}$. As tarifas previstas neste artigo incidirão sobre 0 proprietário ou o explorador da aeronave.

$\S 3^{\circ}$. As tarifas previstas neste artigo serão fixadas pelo Comandante da Aeronáutica, após aprovação do Ministro de Estado da Defesa e manifestação da Agência Nacional de Aviação Civil, para aplicação geral em todo o território nacional. (grifos nossos) 


\section{Marco regulatório: análise constitutional e legislativa}

O serviço de telecomunicações aeronáuticas encontra-se duplamente atrelado à gama de serviços sob competência da União:

Art. 21. Compete à União:

XI - explorar, diretamente ou mediante autorização, concessão ou permissão, os serviços de telecomunicações, nos termos da lei, que disporá sobre a organização dos serviços, a criação de um órgão regulador e outros aspectos institucionais;

XII - explorar, diretamente ou mediante autorização, concessão ou permissão:

c) a navegação aérea, aeroespacial e a infraestrutura aeroportuária;

A competência legislativa sobre o tema igualmente delegou-se à União:

Art. 22. Compete privativamente à União legislar sobre:

IV - águas, energia, informática, telecomunicações e radiodifusão;

X - regime dos portos, navegação lacustre, fluvial, marítima, aérea e aeroespacial;

De acordo com a conformação constitucional, há que se classificar o instituto ora vislumbrado como serviço de telecomunicações para os fins de viabilização da navegação aérea, cuja exploração é disciplinada pela União sobre duplo viés regulatório. Isso significa que, considerando a descentralização de funções do Poder Público Federal, tanto a seara de telecomunicações quanto a de aviação civil terão ascendência regulatória sobre o referido serviço. Cabe ressaltar que essa previsão constitucional tem reflexos diretos no poder normativo das agências reguladoras (Cuéllar, 2001) que se relacionam a essas atribuições constitucionais.

A característica enunciada para as telecomunicações aeronáuticas pode ser verificada em sua conformação jurídica. A modalidade está nominalmente disposta no Código Brasileiro de Aeronáutica (CBA), Lei Federal $\mathrm{n}^{\circ} 7.565$, de 19 de dezembro de 1986, que crivou o ordenamento jurídico com os elementos que compõe o Sistema de Proteção de Vôos, alocando nesse âmbito a atividade: 
Art. 47. O Sistema de Proteção ao Vôo visa à regularidade, segurança e eficiência do fluxo de tráfego no espaço aéreo, abrangendo as seguintes atividades:

$[\ldots]$

II - de telecomunicações aeronáuticas e dos auxílios à navegação aérea;

$[\ldots]$

Art. 48. O serviço de telecomunicações aeronáuticas classificase em:

I - fixo aeronáutico;

II - móvel aeronáutico;

III - de radionavegação aeronáutica;

IV - de radiodifusão aeronáutica;

V - móvel aeronáutico por satélite;

VI - de radionavegação aeronáutica por satélite.

Parágrafo único. 0 serviço de telecomunicações aeronáuticas poderá ser operado:

a) diretamente pelo Ministério da Aeronáutica;

b) mediante autorização, por entidade especializada da Administração Federal Indireta, vinculada àquele Ministério, ou por pessoas jurídicas ou físicas dedicadas às atividades aéreas, em relação às estações privadas de telecomunicações aeronáuticas. (grifos nossos)

Consoante a indicação normativa, as telecomunicações aeronáuticas representam atividade inclusa no Sistema de Proteção de Vôo, que, em conjunto com os auxílios da navegação aérea, dá suporte à regularidade, segurança e eficiência do fluxo de tráfego no espaço aéreo. Importante posicionar que o parágrafo único, acima transcrito, abriu a primeira possibilidade de exploração privada desse serviço, desde sua publicização em 1967, como lembra Campos (2008). Essa regra viria a ser ratificada pela Carta Constitucional de 1988, que disciplinou a delegação de serviços dessa natureza por autorização, permissão ou concessão, conforme a essencialidade da prestação. 
Nesse patamar, classificam-se as telecomunicações aeronáuticas em prestações diversas, conforme o art. 48 do CBA: uma por telefonia fixa (fixo aeronáutico); uma por radiodifusão (radiodifusão aeronáutica); duas por telefonia móvel (móvel aeronáutico e móvel aeronáutico por satélite); e duas por radionavegação (radionavegação aeronáutica e radionavegação aeronáutica por satélite). A norma estipula as possíveis modalidades de telecomunicações aeronáuticas, que devem ser utilizadas conforme a necessidade da malha aeroviária e a capacidade e possibilidade das instalações aeroportuárias. Ou seja, as tecnologias são adaptáveis de acordo com a infraestrutrura de que se dispõe na localidade do país que se requer o serviço.

Sobre o art. 48, comenta Pacheco (2006):

Das diversas atividades de telecomunicações aeronáuticas - 0 serviço de telecomunicações aeronáuticas é regulado por este Código(...)

É ele operado:

a) Pela Aeronáutica através do DEPV (sic)

b) Pela INFRAERO, em substituição a Telecomunicações Aeronáuticas S.A.; ou

c) Pelas pessoas físicas ou jurídicas dedicadas às atividades aeronáuticas, no que diz respeito às estações privadas de telecomunicações aeronáuticas. É o caso, por exemplo, de Camargo Correia que tem frota de aeronaves privadas e aeródromos particulares em suas propriedades e que pode ter estação particular de telecomunicações aeronáuticas. (grifos nossos)

Conforme esclarece Pacheco, as telecomunicações aeronáuticas consubstanciam-se em atividade de proteção do vôo, com tripla interface: Departamento de Controle do Espaço Aéreo do Comando da Aeronáutica e INFRAERO (durante as rotas aéreas), INFRAERO (nos aeroportos) e estações privadas. Isso norteia, inclusive, os níveis de serviço que são prestados, pois aqueles voltados ao transporte aéreo público detêm nível de exigência diferenciado em relação aos serviços de telecomunicação voltados para a aviação particular.

Insta reconhecer que, em relação à operação do serviço, a regra de exploração não foi recepcionada pela Constituição da República Federativa do Brasil de 1988. Com efeito, tendo em vista a extinção do Ministério da 
Aeronáutica, parte dessa exploração direta passou a ser exercida pelo Ministério da Defesa, via DECEA.

A propósito, não se pode perder de vista que as telecomunicações aeronáuticas, apesar de auxiliares ao Sistema de Proteção de Vôo, por definição se subsumem ao conceito de serviço de telecomunicações, por compor conjunto de atividades que possibilita a oferta de telecomunicação, entendida a atividade de transmissão, emissão ou recepção, por fio, radioeletricidade, meios ópticos ou qualquer outro processo eletromagnético, de símbolos, caracteres, sinais, escritos, imagens, sons ou informações de qualquer natureza (art. 60, caput, e $\S 1^{\circ}$ da Lei Federal $\mathrm{n}^{\circ}$ 9.472/1997). Essa natureza, nesse caso, acaba por alocar o serviço enquanto atividade de telecomunicações de apoio, devendo seguir a essencialidade da atividade de aviação civil à qual se presta.

Dessa maneira, considerando-se tratar de serviço eminentemente de telecomunicações, a regência de sua outorga deve ser examinada nos termos da Lei Federal $n^{\circ}$ 9.472, de 16 de julho de 1997, que dispõe sobre a organização dos serviços de telecomunicações. Nesse aspecto, pelo princípio da lex specialis derogat legi generali, somente segundo a referida lei se está autorizado a produzir interpretação abalizada que identifique o regime de outorga das telecomunicações aeronáuticas - consultadas as autoridades de aviação civil pertinentes ao processo.

Cumpre observar que a Lei Geral de Telecomunicações (LGT) reservou somente um dispositivo para tratar, de maneira tangencial, das telecomunicações aeronáuticas, in verbis:

Art. 162. A operação de estação transmissora de radiocomunicação está sujeita à licença de funcionamento prévia e à fiscalização permanente, nos termos da regulamentação.

$\S 3^{\circ} \mathrm{A}$ emissão ou extinção da licença relativa à estação de apoio à navegação marítima ou aeronáutica, bem como à estação de radiocomunicação marítima ou aeronáutica, dependerá de parecer favorável dos órgãos competentes para a vistoria de embarcações e aeronaves. (grifos nossos)

O dispositivo enunciado revela, de maneira direta, que a responsabilidade pela emissão ou extinção da licença referente às estações de comunicação não dependerá exclusivamente da entidade reguladora das 
telecomunicações, mas também dos entes atrelados à aviação civil, confirmando a premissa acima mencionada. Essa tutela processual administrativa denota a importância de uma análise plural acerca do tema, que envolva domínios aparentemente distintos de conhecimento técnico.

Disso se depreende, ainda que de forma indireta, que o referido artigo força o intérprete da norma jurídica a questionar qual a classificação adequada, na disciplina da Lei Federal $n^{\circ}$ 9.472/97, para as atividades que envolvem as telecomunicações aeronáuticas. Essa indicação, que torna clara a composição heterogênea do marco regulatório que se perquiria, partindo da Constituição da República Federativa do Brasil e ecoando tanto no CBA, quanto na LGT, dá o tom para a problematização da natureza do serviço que ora se discute.

\section{Natureza jurídica das telecomunicações aeronáuticas}

Para compor essa classificação, considerando tratar-se de serviço de telecomunicações, como acima configurado, mister seguir roteiro insculpido na referenciada LGT. Prevê a norma infraconstitucional acerca da abrangência da prestação:

Art. 62. Quanto à abrangência dos interesses a que atendem, os serviços de telecomunicações classificam-se em serviços de interesse coletivo e serviços de interesse restrito.

Sobre esse dualismo de interesses, esclarece Salomão (2008):

Enquanto o conceito de interesse privado é bastante curial, resumindo-se ao interesse individual, sobre o conceito de interesse público pairam de há muito importantes divergências conceituais. (...)

No presente trabalho será adotado um terceiro conceito, muito mais ligado à etimologia e - mais importante que isso - às origens do conceito. Segundo o clássico dicionário etimológico latino de WaldeHoffman, o termo publicus tem duas possíveis origens etimológicas diversas. Uma pode ter sido a palavra poplicus, usada nas fontes como sinônimo de populus. Uma segunda origem possível seria a palavra publicus, usada para identificar o povo com capacidade política. Qualquer que seja a origem, ressalta a ligação do conceito à idéia de povo. $\mathrm{O}$ próprio conceito de Estado em Roma está, de resto, ligado à idéia de povo, não existindo dele uma entidade separada. 
Daí resulta a noção de interesse público como interesse da coletividade, do povo como um todo - portanto, interesse de todos.

É certo que especificamente o Serviço de Radiocomunicação Móvel é classificado como restrito pelo Decreto $\mathrm{n}^{\circ}$ 97.057/88, mas este compõe apenas uma das modalidades de telecomunicações aeronáuticas disponíveis. Inviável, assim, que se admita cuidar-se, em todas as modalidades anunciadas, de serviço de interesse restrito em seu bojo. Isso decorre da imprescindibilidade da atividade de aviação civil, que atende a interesse coletivo de segurança e proteção dos vôos, bem como afeta interesses de terceiros, vez que sua prestação defeituosa pode causar terríveis impactos na sociedade. Para além de viabilizarem o transporte aéreo, as telecomunicações aeronáuticas compõem item de segurança nacional ao auxiliarem a vigilância das fronteiras.

Vale então, de forma geral, antecipando a designação técnica dos institutos, expor que, para os fins da presente análise, o foco deste estudo recai sobre o Serviço Móvel Aeronáutico (SMA), estabelecido entre as estações de telecomunicações e os pilotos, que, se voltado ao transporte aéreo público, terá características de interesse coletivo, mas se direcionado ao transporte aéreo privado, comportará alcunha de interesse restrito.

Para comprovar a assertiva de maneira satisfatória, toma relevo a visualização do regime jurídico da prestação. A propósito, estabelece a LGT, quanto ao tema:

Art. 63. Quanto ao regime jurídico de sua prestação, os serviços de telecomunicações classificam-se em públicos e privados.

Parágrafo único. Serviço de telecomunicações em regime público é o prestado mediante concessão ou permissão, com atribuição a sua prestadora de obrigações de universalização e de continuidade.

Art. 64. Comportarão prestação no regime público as modalidades de serviço de telecomunicações de interesse coletivo, cuja existência, universalização e continuidade a própria União comprometa-se a assegurar.

Parágrafo único. Incluem-se neste caso as diversas modalidades do serviço telefônico fixo comutado, de qualquer âmbito, destinado ao uso do público em geral. 
Consoante normatizado, achou por bem o legislador em bipartir o serviço de telecomunicações sob as formas de prestação pública e privada. Caso seja pública, deve sujeitar-se a concessão ou permissão; caso privada, à luz dos dispositivos constitucionais acima elencados, delega-se por autorização, que nesse caso representa ato vinculado. ${ }^{4}$

Para direcionar essa questão, o art. 64 da LGT anuncia que comportam o regime público os serviços de interesse coletivo, nos quais a União garanta sua existência, universalização e continuidade. Seu parágrafo único inclui, expressamente, entre esse rol não enunciado, as diversas modalidades de serviço telefônico fixo comutado. Não obstante, há espaço para a inclusão de outras prestações, não expressas, que cabem no conceito de interesse público.

Voltando os olhos à configuração do regime de prestação das telecomunicações aeronáuticas, temos pré-fixado tratar-se de serviço de interesse coletivo, no caso de transporte aéreo público (art. 175 do CBA) -

4 “A autorização na Lei Geral de Telecomunicações é muito diferente daquilo que nós vimos na doutrina clássica administrativista. A razão principal para esse fato é que o legislador achou por bem tratar a autorização em matéria de serviços de telecomunicação de maneira diferenciada, por considerar superada a velha doutrina de classificação. A definição de autorização apresentada pela doutrina serviu durante muito tempo. No setor de telecomunicações, porém, não vale a classificação doutrinária. O legislador não considerou a autorização de telecomunicações um ato discricionário, mas sim um ato vinculado. Tem se verificado, aqui ou acolá, críticas à possibilidade de exigência legal de autorização para exploração de atividade econômica. No nosso entender, não avistamos óbices para a exigência de autorização para o setor de telecomunicações. A Constituição Federal, em seu art. 170, parágrafo único, dispõe que 'é assegurado a todos o livre exercício de qualquer atividade econômica, independentemente de autorização de órgãos públicos, salvo nos casos previstos em lei'. Sendo assim, se o constituinte disse isto é porque admitiu que, quando a lei entender conveniente, esta poderá exigir autorização para a exploração de determinada atividade econômica. Além disso, como mencionamos, a Emenda Constitucional 8, de 1995, introduziu no art. 21, XI, da Constituição Federal a perspectiva de que o serviço de telecomunicações será objeto de autorização, concessão ou permissão. Nesse sentido, o art. 175 da Constituição Federal dispõe que a prestação de serviços públicos incumbe ao Poder Público diretamente ou sob o regime de permissão ou concessão. Ou seja, os serviços que não são prestados em regime público, mas sim em regime privado, devem ser objeto de autorização, por força do art. 21, XI, combinado com o art. 175, ambos da Constituição Federal. Só assim se consegue a necessária integração sistêmica do texto constitucional." (Azevedo Marques, 2000). 
como dito, modalidade de telecomunicação que se orienta pela essencialidade ao serviço que suporta. Nesse gancho, importa perceber que, até pelas evidências históricas, a União tem assegurado a sua existência e continuidade - sobretudo quando se considera que, desde sua publicização, manteve o serviço sob prestação direta ou atrelado a empresas públicas, subjugadas ao Ministério da Aeronáutica ou Defesa. Mas de outra forma também não poderia ser, considerada a sua essencialidade para a proteção dos vôos.

No que tange à universalização, no entanto, essa não se tem configurado uma diretriz regulatória. Com efeito, como se verá na descrição técnica do funcionamento do serviço, em si, as rotas aéreas compõem trilhos sobre as infraestruturas de telecomunicações, integradas por Estações Prestadoras de Serviços de Telecomunicações e Tráfego Aéreo - EPTA (Campos, 2008), para que se possa auxiliar a navegação das aeronaves até os aeroportos (Figura 1). Nesse caso, a universalização representaria a expansão da infraestrutura disponível para telecomunicações aeronáuticas, de modo a compor maior número de rotas seguras para as empresas aéreas.

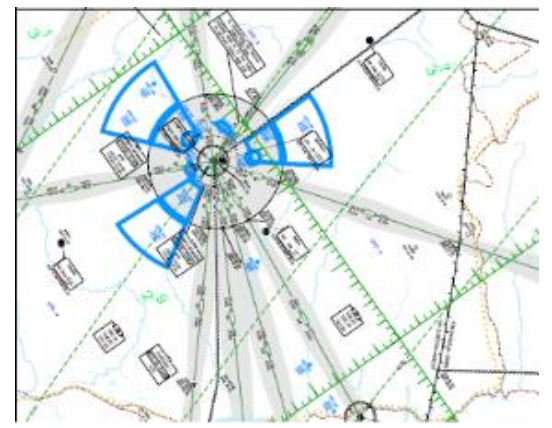

Figura 1 - Recorte da Carta Aeronáutica da rota ENRC_L2 (Região de Campo Grande/MS). (Ministério da Defesa, 2010) 
Como se ilustra na Figura 1 acima $^{5}$, a área redonda em tonalidade cinza representa a cobertura de telecomunicações acima do aeroporto de Campo Grande, sendo que as linhas cinza descrevem as aerovias, cujo ponto de origem reside naquela localidade. Como se pode observar, grande parcela da área está sob a tonalidade branca. Esta não possui o serviço de telecomunicações - áreas de sombra -, o que impossibilita a navegação das aeronaves por esses sentidos, revelando, a título de exemplo, a parcela do espaço aéreo no qual não se pode trafegar por inviabilidade técnica, ou seja, por ausência de meios que permitam uma orientação segura dos pilotos. A figura também mostra as áreas destinadas a exercícios militares, delineadas em azul, sendo certo que dentro desse espaço aéreo condicionado não se permite a prestação de serviços de tráfego aéreo.

A despeito de a universalização não representar o foco central regulatório para esse serviço, observa-se ser intrínseca essa necessidade para a manutenção e crescimento do transporte aéreo do país, que encontra sua regularidade geminada à sua pontualidade, o que é inviável sem um sistema de navegação aérea confiável, que há de se apoiar em um serviço de telecomunicações universal e contínuo. Disso se depreende a obrigatoriedade de a União viabilizar a ampliação do serviço para o caso do serviço público de transporte aéreo de passageiros, conforme a disciplina do art. 175 do CBA.

A partir dessa dedução, pode-se afirmar que parcela das telecomunicações aeronáuticas, em seu bojo, estaria sujeita à prestação jurídica em regime público. Em razão disso, admite-se que, para os fins de proteção de vôos e segurança aeronáutica, destinados ao transporte aéreo público, o regime do serviço de telecomunicações aeronáuticas deve se sujeitar à outorga por concessão ou permissão. Por outro lado, as prestações voltadas para os serviços aéreos privados estariam sujeitas à autorização. Essa interpretação se justifica, inclusive, face ao $\S 1^{\circ}$ do art. $8^{\circ}$ da Lei $n^{\circ}$ 6.009/73, acima transcrito.

${ }^{5}$ Carta Aeronáutica de rotas, referente à ENRC_L2, extraída do sítio http://ais.decea.gov.br/?i=cartas, consultado em $1^{\circ}$ de fevereiro de 2013. Importa esclarecer que se trata de uma Carta de Navegação Visual, que serve para apoiar os vôos, que utilizam a navegação com referência visual do solo (Almeida et al., 2009). 
Ressalte-se que ora não se afirma que se cuida de serviço público strictu sensu, a ponto de contestar o Decreto que permitiu a incorporação da TASA à INFRAERO, elemento que pouco afeta os rumos do presente trabalho que busca investigar, em última análise, o regime da outorga desses serviços de telecomunicações. Contudo, é forçoso admitir, ao menos, que se cuida de serviço de interesse coletivo.

Dadas as peculiaridades da delegação e o regime jurídico da prestação, há que se indicar sua exclusividade ou concomitância. Disciplina a LGT:

Art. 65. Cada modalidade de serviço será destinada à prestação:

I - exclusivamente no regime público;

II - exclusivamente no regime privado; ou

III - concomitantemente nos regimes público e privado.

$\S 1^{\circ}$ Não serão deixadas à exploração apenas em regime privado as modalidades de serviço de interesse coletivo que, sendo essenciais, estejam sujeitas a deveres de universalização.

$\S 2^{\circ} \mathrm{A}$ exclusividade ou concomitância a que se refere o caput poderá ocorrer em âmbito nacional, regional, local ou em áreas determinadas.

Art. 66. Quando um serviço for, ao mesmo tempo, explorado nos regimes público e privado, serão adotadas medidas que impeçam a inviabilidade econômica de sua prestação no regime público.

$\mathrm{Na}$ linha do que foi comentado, verifica-se que o regime público de prestação do serviço sob estudo atrela-se ao transporte aéreo público, da mesma forma que o regime privado corresponde ao transporte particular. Nesse caso, a aplicação do art. 66 será adotado in totum, para se garantir a continuidade do serviço.

Para encerrar esse âmbito de discussão, cabe lembrar que o regime de exploração atual não restou afetado pela disciplina da LGT, com fundamento no comando constitucional que manteve as outorgas em vigor. Enfatize-se que a designação concessões há que ser entendida como delegação lato sensu, considerada a disciplina peculiar de exploração de cada serviço antes da Lei Geral de Telecomunicações.

Art. 66. São mantidas as concessões de serviços públicos de telecomunicações atualmente em vigor, nos termos da lei. (Ato 
das Disposições Constitucionais Transitórias da Constituição Federal de 1988)

\section{Atividades de telecomunicações aeronáuticas}

Em seu sítio eletrônico ${ }^{6}$, o DECEA descreve as atividades de telecomunicações aeronáuticas atualmente utilizadas: o Serviço Móvel Aeronáutico (SMA), destinado à comunicação entre controladores de tráfego e pilotos; o Serviço Fixo Aeronáutico (SFA), para a comunicação entre os diferentes órgãos de controle e a Rede Internacional Fixa de Telecomunicações Aeronáuticas (AFTN, Aeronautical Fixed Telecommunications Network). Os dois primeiros são mantidos pelo próprio DECEA, dentro de suas atribuições regulamentares.

Vale detalhar que, conforme destaca o mencionado sítio eletrônico do DECEA, o SMA é composto por estações para radio-comunicação esparsas no território nacional, que compõem os trilhos acima enunciados (Figura 1), contabilizando mais de 380 estações no país. Esse sistema é compartilhado com os operadores das empresas aéreas, uma vez que a duplicação desse sistema de comunicação seria extremamente dispendioso. O serviço está previsto no Decreto $\mathrm{n}^{\circ}$ 97.057, de 10 de novembro de 1988 e hoje também se submete à regulamentação da Agência Nacional de Telecomunicações. Nas informações técnicas sobre as comunicações via rádio, dispostas no sítio eletrônico da ANATEL $^{7}$, encontram-se os seguintes esclarecimentos sobre o SMA:

Categoria de serviço móvel em que as estações móveis deslocam-se por via aérea e comunicam-se com estações terrestres do serviço móvel aeronáutico, denominadas Estações Aeronáuticas. Os serviços de telecomunicações aeronáuticas são prestados em condições e em faixas de frequiência dos serviços Fixo e Móvel Aeronáutico, de Radionavegação Aeronáutica e de Radiodeterminação, definidas no Regulamento de Radiocomunicações da União Internacional de Telecomunicações (UIT), no Plano de Atribuição, Destinação e Distribuição de Faixas de Frequiências no Brasil, no Anexo 10 da ICAO,

${ }^{6}$ In: http://www.decea.gov.br/espaco-aereo/telecomunicacoes-aeronauticas/, consultado em 5 de janeiro de 2013.

${ }^{7}$ In: www.anatel.gov.br, consultado em 8 de janeiro de 2013. 
no Código Brasileiro de Aeronáutica, na Lei Geral de Telecomunicações e em outros que venham a ser assim considerados pela Legislação Brasileira.

O SFA, por outro lado, congrega os órgãos de controle de tráfego aéreo, por intermédio das denominadas hot lines, tendo em vista a necessidade de comunicações operacionais imediatas. Por essas redes, coordena-se todo o tráfego aéreo nacional, civil e militar.

Interessante ainda comentar que a ANATEL vem discutindo a abertura de frequiências para o Serviço Limitado Móvel Especializado, do qual o Aeronáutico e o Marítimo fazem parte, como se vislumbra na Consulta Pública $\mathrm{n}^{\circ} 18$, de 8 de maio de 2009, disposta no sítio eletrônico daquela Agência, com vistas a ampliar as possibilidades da emissão de autorização para a execução dos serviços e para o licenciamento de estações transmissoras de radiocomunicação voltadas a frotas próprias.

Por sua vez, a AFTN tem viés para a aviação internacional, integrando os órgãos de controle aéreo brasileiros com os dos países vizinhos, para viabilizar a transferência de tráfego aéreo e as mensagens de cunho operacional. A AFTN representa a rede internacional de telecomunicações integrada pelos órgãos de controle de vôos de diferentes países fronteiriços, essencial para a transferência segura do tráfego aéreo. Em termos conceituais, representa dever desses órgãos situados nos países de origem entregar o fluxo das aeronaves aos países de destino. Faz-se, portanto, fundamental para a troca de mensagens operacionais, em especial relacionadas ao destino das aeronaves, às condições climáticas e de operação dos aeródromos, tráfego nas aerovias e a coordenação dos centros de controle, entre outras funcionalidades. Sua malha é extensa e capilarizada, permitindo que as aeronaves possam viajar para diversos destinos.

Ainda sobre a rede internacional de telecomunicações aeronáuticas, consoante noticia o sítio eletrônico do DECEA, criou-se, em 1993, pela Organização de Aviação Civil Internacional (OACI) um grupo para estudar, identificar e elaborar, com vistas às inovações tecnológicas, novos conceitos para as telecomunicações e navegação aérea, denominado Comitê Future Air Navigation Systems (FANS). A grande contribuição desse grupo foi o conceito de Comunications, Navigation and Survellance/Air Traffic 
Management (CNS/ATM), pelo que se identificaram dois temas essenciais para a navegação aérea: o uso intensivo de comunicação de dados e o emprego de sistemas baseados em satélites, que mais tarde evoluiria para a navegação por GPS.

\section{Disciplina regulamentar}

$\mathrm{Na}$ esfera técnica, as telecomunicações aeronáuticas são regidas pelo Anexo 10 da Convenção Internacional para a Aviação Civil. Nessa convenção, foi também criada a Organização de Aviação Civil Internacional (OACI), para desempenhar o papel de organizador e atualizador dessas normas.

No Brasil, a matéria foi disciplinada pela Portaria DECEA $\mathrm{n}^{\circ}$ 54/DGCEA, de 4 de março de 2008, que aprovou a edição do Manual que estabelece as normas e os procedimentos de telecomunicações no âmbito do Comando da Aeronáutica (MCA 102-7) e pela Portaria DECEA n ${ }^{\circ}$ 9/SDOP, de 16 de abril de 2012 (ICA 63-10), que aprova a reedição da instrução que estabelece as normas e procedimentos para a implantação, homologação, ativação, operação, fiscalização, controle e desativação de Estações Prestadoras de Serviços de Telecomunicações e de Tráfego Aéreo (EPTA). Essas normas descrevem os padrões de comunicação e a utilização das redes de telecomunicações, as formas da operação e da utilização das Telecomunicações Aeronáuticas, consoante o Anexo 10 da OACI, bem como as regras para o estabelecimento e funcionamento de uma EPTA.

$\mathrm{Na}$ área das telecomunicações, a regulamentação da Licença de Estação de Aeronave foi exercida pela Instrução Interna DENTEL n 6/88, de 27 de dezembro de 1988, que estabeleceu os procedimentos para análise de pedidos e expedição. Com o advento do art. 162, § $3^{\circ}$ da LGT, a Agência Nacional de Telecomunicações (ANATEL) passou a partilhar esse processo de autorização e licença das referidas estações com a autoridade reguladora aeronáutica, que passou a ser a Agência Nacional de Aviação Civil (ANAC), a partir de 2005.

Por esse sistema normativo, os interessados em prestar o serviço se estruturam de acordo com as normas aeronáuticas e solicitam a sua faixa de frequiência conforme a regulamentação das telecomunicações, o que assevera a natureza mista do instituto. Daí a atuação conjunta das Agências 
de Aviação Civil e Telecomunicações. Por sua vez, a fiscalização resta compartilhada entre os entes.

Ultrapassados os procedimentos para obtenção da frequência das faixas de telecomunicações para as aeronaves, vale ainda mencionar que algumas normas são essências para o gerenciamento do espaço aéreo. São essas normas que tratam dos espaços aéreos condicionados, da implantação dos órgãos de comunicação, do sistema de pouso por instrumentos e das regras do ar e do serviço de navegação aérea.

Dessa forma, a AIP-Brasil ENR 5.1 classifica as áreas condicionadas em restritas, perigosas e proibidas, listando todos os locais nos quais existe essa limitação de tráfego e indicando seus limites inferiores, superiores e laterais, que é a forma pela qual se dimensiona uma região no espaço. Nessas localidades, o serviço de telecomunicações é provido, a rigor, pelo DECEA para aeronaves militares.

Outra norma que merece menção é a ICA 63-18, aprovada pela Portaria DECEA/DGCEA n ${ }^{\circ}$ 69, de 18 de abril de 2006, que trata da implantação dos órgãos de telecomunicação e auxílio à navegação aérea. A referida instrução fornece os parâmetros para a instalação de equipamentos de telecomunicações, elencando critérios e prioridades para sua alocação. Vale comentar que o procedimento de pouso por instrumentos rege-se pela ICA 100-16, aprovada pela Portaria DECEA n ${ }^{\circ}$ 213/NOR1, de $1^{\circ}$ de setembro de 2011.

Cabe ênfase, ainda, à ICA 100-12, aprovada pela Portaria DECEA/SDOP $\mathrm{n}^{\circ}$ 5, de 27 de fevereiro de 2009, que disciplina as regras do ar e da navegação aérea. Essa interessante norma baliza a navegação aérea e a interação das aeronaves com os agentes que orientam o vôo e se faz essencial para a atividade que ora se comenta.

\section{Dinâmica das telecomunicações aeronáuticas}

A dinâmica das telecomunicações aeronáuticas é decisiva para a produção do transporte aéreo. Destarte, seguindo as orientações da ICA 100-12 acima mencionada, faz-se imprescindível para o presente estudo a descrição dessa atividade. É possível expor o papel das telecomunicações para o transporte aéreo, com ênfase em cada uma das etapas em que o serviço é utilizado para viabilizar a navegação aérea. 
Previamente, cumpre explicar, conforme esclarece a ICA 63-18, que existem quatro órgãos que prestam o serviço de tráfego aéreo (ATS): a Estação de Telecomunicações Aeronáuticas (RADIO) ${ }^{8}$, a Torre de Controle de Aeródromo (TWR), o Controle de Aproximação (APP) e o Centro de Controle de Área (ACC). Todos esses órgãos interagem com a aeronave, da origem ao destino de seu percurso, restando importante salientar que tem cobertura diferenciada de telecomunicações sobre a área.

A produção da atividade de telecomunicação aeronáutica tem um prérequisito na aprovação pelo Sistema de Informação Aeronáutico (AIS) do plano de vôo da aeronave. Essa aeronave já apresentou para a aprovação dos órgãos reguladores (ANAC e DECEA) um plano de vôo, no qual, segundo as rotas aeronáuticas, detalha seu caminho e pontos de parada. Para fins de navegação aérea, compete ao DECEA, pelo D-GNA aprovar esse plano (Ministério da Defesa, 2011b).

Com essa regra pré-estabelecida, estará apto o piloto a iniciar sua operação de transporte aéreo. Ainda com a aeronave desligada, deve se comunicar com a torre do aeródromo. A TWR tem três funções precípuas: autorizar o tráfego inicial, exercer o controle de solo e liberar a decolagem. Nesse primeiro momento, o comandante da aeronave pede autorização para seguir a rota conforme o plano de vôo pré-aprovado. Somente após esse procedimento poderá ligar a sua aeronave.

Com a aeronave ligada, nova comunicação deverá ser realizada para verificar junto ao controle de solo se pode levar seu veículo até a pista. Passado esse procedimento, comunica-se com a torre para solicitar a permissão para decolagem da aeronave. A figura 2 abaixo ilustra a área de reponsabilidade sob a tutela da torre de comando.

${ }^{8}$ A rádio proporciona serviço de informação de vôo num raio de 50 quilômetros do aeródromo (Ministério da Defesa, 2010). 


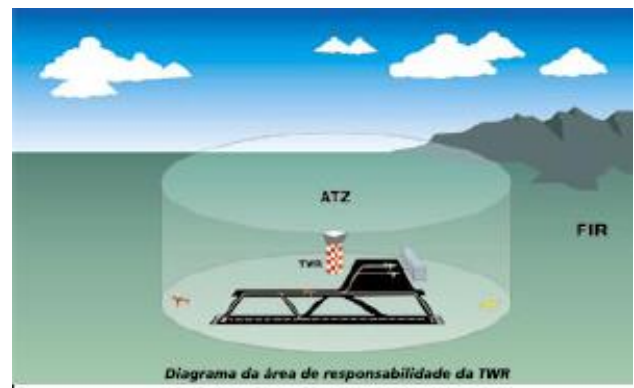

Figura 2 - Área de Cobertura da TWR (Ministério da Defesa, 2010)

Como se observa, a área de comunicação da TWR engloba toda a região acima do aeródromo, abrangendo todo o circuito de tráfego e manobras ao redor deste. A função de torre é essencial para a orientação da decolagem, pouso e sobrevôo, de forma a evitar fatalidades (Ministério da Defesa, 2010).

Ato contínuo, o piloto deve interagir com o APP, que tem por função essencial realizar uma separação das aeronaves e indicação de suas posições no aeródromo. A área de atuação do APP é um espaço designado como Área de Controle do Terminal (ATM) ou Zona de Controle (CTR), que abrange um ou mais aeródromos na região, conforme o fluxo de tráfego (Ministério da Defesa, 2010). Para o APP, o piloto informa sua rota e a aerovia que deverá tomar, permitindo que o APP tenha sua posição e possa separá-lo das demais aeronaves que deixam a região. A figura 3 indica a atuação do APP:

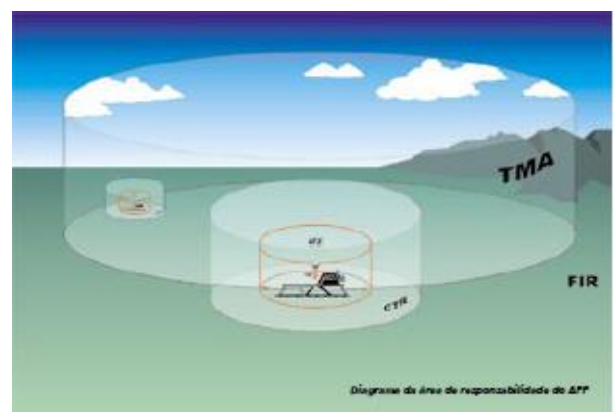

Figura 3 - Área de responsabilidade do APP (Ministério da Defesa, 2010) 
A partir daí, o piloto deverá se comunicar com o ACC, que tem por missão não só a separação das aeronaves, mas especialmente o fornecimento de informações durante o vôo, permitindo, assim, a condução do piloto pela aerovia, na qual recebeu autorização para trafegar, informando sua posição na entrada, na saída e a cada trinta minutos, caso não mude de aerovia antes. A figura 4 ilustra a produção da atividade que se acaba de descrever, bem como a cobertura de cada órgão de comunicação.

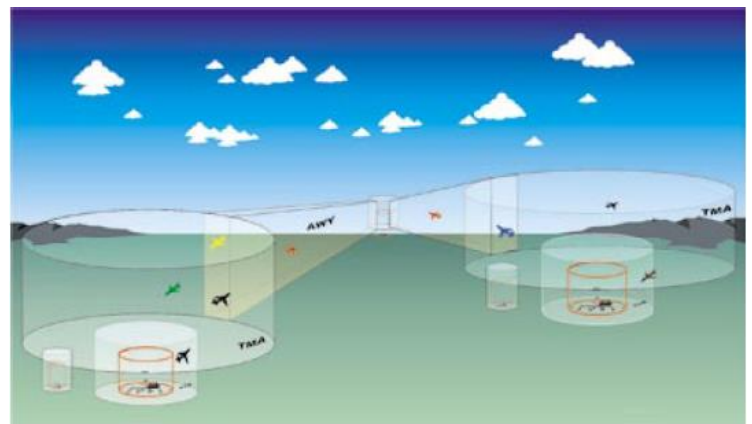

Figura 4 - Espaços aéreos controlados (Ministério da Defesa, 2010)

Cabe observar que os cilindros vermelhos pequenos referem-se ao alcance da TWR, os cilindros médios e grandes ao da APP e as rotas ao da ACC. No procedimento de pouso, o piloto deve realizar o caminho de telecomunicações inverso ao da decolagem, sendo que primeiro se comunica com a ACC da região, depois APP e finalmente com a TWR. A rigor, o controle de solo exercido pela TWR já detém informações sobre a ponte de desembarque, posição que a aeronave irá ocupar no aeroporto, situação de permanência, passageiros que desembarcam e próximo destino do veículo.

Ressalte-se que durante todo o percurso na aerovia, as aeronaves ainda têm o sistema de vigilância por radar, que realiza o controle das manobras do piloto e a vetoração da aeronave, serviço esse executado pelo controlador de vôo. Abaixo a figura 5 retrata um diagrama de responsabilidade por níveis. 


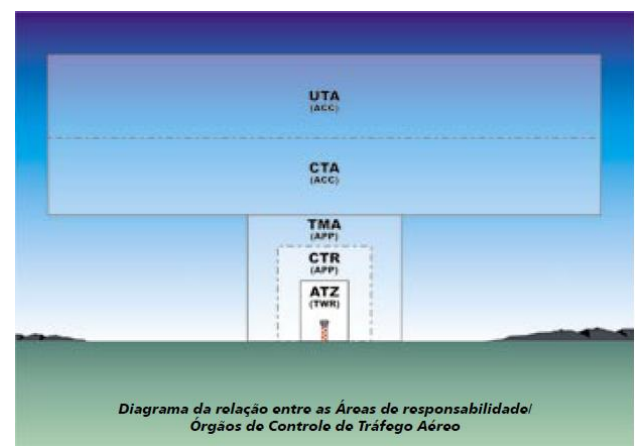

Figura 5. Área de responsabilidade dos Órgãos de Controle do Tráfego Aéreo (Ministério da Defesa, 2010)

Segundo publicação do DECEA (Ministério da Defesa, 2010), existem 90 RADIO, 59 TWR, 47 APP e 5 ACC, estas últimas referentes às regiões brasileiras. Cumpre comentar que as entidades de telecomunicações têm precedência conforme sua abrangência, sendo certo afirmar que a ACC tem preeminência na autorização de vôos cuja origem seja na sua região de informação de vôo (FIR).

Finalmente, há que se contextualizar nesse bojo as Empresas Prestadoras de Serviços de Telecomunicações e de Tráfego Aéreo (EPTA), não localizadas nos aeródromos, também disciplinadas pela ICA 63-10. De acordo com a norma competente, tais entidades podem ser públicas ou privadas, nos termos do CBA (art. 48, parágrafo único, alínea $b$ ), e devem ser homologadas e autorizadas pelo DECEA.

Enquanto unidades autônomas de comunicação, devem ser dotadas de pessoas e de equipamentos necessários para prover os serviços de controle de tráfego aéreo, apoiar o trânsito de aeronaves pelos serviços auxiliares à navegação aérea, veicular mensagens de caráter geral, sempre agindo em complemento à rede gerida pelo Comando da Aeronáutica (DECEA).

Interessante destacar que muitas dessas EPTAs são administradas por entes públicos municipais para o fomento da circulação de aeronaves em sua região. 


\section{Do regime tarifário e tributário}

Em breve cotejo descritivo, uma vez que não se traz por tônica, no presente estudo, a questão da adequada remuneração dos serviços de telecomunicações aeronáuticas, vale expor o regime tarifário que sustenta essa rede a que se sujeitam os prestadores. Sobre a imposição da remuneração por tarifas, esclarece Sundfeld (2000):

Compreender o regime jurídico das atividades estatais exploradas por particulares supõe, portanto, a pesquisa e considerações da legislação de regência. (...)

A regulação de serviços de interesse geral pode envolver diferentes tipos de interferência estatal em matéria de preços (tarifas). Um serviço regulado (quanto aos mais variados aspectos, como padrões de qualidade, estrutura de mercado do setor, compartilhamento de infraestrutura etc.) pode sujeitar-se à liberdade tarifária, em virtude da qual os preços serão determinados pelos próprios prestadores, em função da competição de suas estratégias empresariais, do comportamento da economia etc. Assim, um serviço regulado quanto a um aspecto pode ser desregulado quanto aos preços, tudo na dependência da política estatal estabelecida em lei.

As atividades de titularidade estatal exploradas por particulares são passíveis de sujeç̧ão ao regime de liberdade de preços, não havendo qualquer impedimento constitucional a respeito. São muitos os casos de atividades federais cuja exploração por particulares é admitida sem que a União exerça o controle direto quanto aos preços praticados. Menciono, sem qualquer intenção de ser exaustivo, os serviços de (...) transporte aéreo público não-regular (...)

A política tarifária, insista-se, é determinada pela lei, e não pela Constituição. Assim, cabe à lei escolher entre as possíveis opções no tocante à regulação dos preços. Não faz sentido, ademais, supor que a natureza estatal das atividades envolvidas seria incompatível com a fruição, pelo explorador privado, de liberdade econômica relativa a preços. Observe-se que a regulação oficial de preços não é limitada aos serviços de titularidades estatal, podendo a lei prevê-la relativamente a serviços próprios da iniciativa privada, com finalidades sociais, ou em situações conjunturais. Portanto, não é a natureza da atividade nem seu enquadramento no campo estatal ou privado que justificam ou 
impõem a regulação de preços, ou inviabilizam a adoção de um outro método de regulação. (...)

A competência para o controle de tarifa, especialmente quando em seu grau máximo, não pode, todavia, ser exercida sem base legal e regulamentar, e muito menos contra as normas em vigor. Assim, ou ela é conferida pela lei e seus regulamentos, ou ela não existe (CF, art. 175, parágrafo único, III) (grifos nossos)

Observa-se que o autor fixa uma premissa essencial: a política tarifária se submete ao princípio da legalidade. Disso pode-se depreender que, uma vez estabelecida a política em lei, cabe ao ente regulador regulamentá-la e ditar os valores aplicáveis.

Em relação à política tarifária sobre os serviços de transporte aéreo, inclusive como mecanismo regulatório, orientou o CBA:

Art. 14. No tráfego de aeronaves no espaço aéreo brasileiro, observam-se as disposições estabelecidas nos Tratados, Convenções e Atos Internacionais de que o Brasil seja parte $\left(\operatorname{artigo} 1^{\circ}, \S 1^{\circ}\right)$, neste Código $\left(\operatorname{artigo} 1^{\circ}, \S 2^{\circ}\right)$ e na legislação complementar $\left(\operatorname{artigo} 1^{\circ}, \S 3^{\circ}\right)$

$\S 4^{\circ}$ A utilização do espaço aéreo brasileiro, por qualquer aeronave, fica sujeita às normas e condições estabelecidas, assim como às tarifas de uso das comunicações e dos auxílios à navegação aérea em rota (artigo 23).

Art. 193. Os serviços aéreos de transporte regular ficarão sujeitos às normas que o Governo estabelecer para impedir a competição ruinosa e assegurar o seu melhor rendimento econômico podendo, para esse fim, a autoridade aeronáutica, a qualquer tempo, modificar freqüências, rotas, horários e tarifas de serviços e outras quaisquer condições da concessão ou autorização.

Art. 200. Toda empresa nacional ou estrangeira de serviço de transporte aéreo público regular obedecerá às tarifas aprovadas pela autoridade aeronáutica.

Parágrafo único. No transporte internacional não regular, a autoridade aeronáutica poderá exigir que o preço do transporte seja submetido a sua aprovação prévia.

Consoante emerge do comando geral normativo, compete à autoridade aeronáutica regulamentar e normatizar as tarifas que pendem sobre o setor aeroportuário e aeronáutico. Ressalte-se que se cuida de regime por tarifa 
teto, não sendo impedido que o operador da telecomunicação estabeleça preços abaixo do valor regulado pelo DECEA. Com fulcro nessa política geral traçada pelo CBA, a Lei $\mathrm{n}^{\circ}$ 6.009, de 26 de dezembro de 1973, alterada pela Lei $\mathrm{n}^{\circ} 12.648$, de 17 de maio de 2012 (Medida Provisória $\mathrm{n}^{\circ}$ 551, de 22 de novembro de 2011), deu a tônica da tarifação dos serviços de navegação, no qual se incluem as telecomunicações aeronáuticas:

Art. $8^{\circ}$. A utilização das instalações e serviços destinados a apoiar e tornar segura a navegação aérea, proporcionados pelo Comando da Aeronáutica, está sujeita ao pagamento das seguintes tarifas de navegação aérea:

I - Tarifa de Uso das Comunicações e dos Auxílios à Navegação Aérea em Rota - devida pela utilização do conjunto de instalações e serviços relacionados ao controle dos vôos em rota, de acordo com as normas específicas do Comando da Aeronáutica;

II - Tarifa de Uso das Comunicações e dos Auxílios-Rádio à Navegação Aérea em Área de Controle de Aproximação devida pela utilização do conjunto de instalações e serviços relacionados ao controle de aproximação, de acordo com as normas específicas do Comando da Aeronáutica;

III - Tarifa de Uso das Comunicações e dos Auxílios-Rádio à Navegação Aérea em Área de Controle de Aeródromo - devida pela utilização do conjunto de instalações e serviços relacionados ao controle de aeródromo ou aos serviços de informações de vôo de aeródromo, de acordo com as normas específicas do Comando da Aeronáutica.

$\S 1^{\circ}$. Os serviços de que trata 0 caput poderão, a critério do Comando da Aeronáutica, ser prestados por outros órgãos e entidades públicos e privados.

$\S 2^{\circ}$. As tarifas previstas neste artigo incidirão sobre 0 proprietário ou o explorador da aeronave.

$\S 3^{\circ}$. As tarifas previstas neste artigo serão fixadas pelo Comandante da Aeronáutica, após aprovação do Ministro de Estado da Defesa e manifestação da Agência Nacional de Aviação Civil, para aplicação geral em todo o território nacional.

A norma que inicialmente regulamenta o mencionado dispositivo legal foi o Decreto $\mathrm{n}^{\mathrm{o}}$ 89.121, de 6 de dezembro de 1983, atribuindo para o 
serviço de telecomunicações o pagamento de preço específico, quando se utilizar de facilidades do aeroporto:

Art. $2^{\circ}$ A efetiva utilização de áreas, edifícios, instalações, equipamentos, facilidades e serviços de um aeroporto está sujeita ao pagamento referente aos preços que incidirem sobre a parte utilizada.

Parágrafo único. Os preços de que trata este artigo serão pagos a entidade responsável pela administração do aeroporto, e serão representados por:

a) tarifas aeroportuárias, aprovadas pelo Ministro da Aeronáutica, para aplicação geral em todo o território nacional; e

b) preços específicos, estabelecidos pela entidade responsável pela administração do aeroporto.

(...)

Art. 11 Os preços específicos a que se refere a letra "b" do parágrafo único do artigo $2^{\circ}$ deste Decreto, serão os preços mínimos cobrados dos usuários, pela utilização de áreas, edifícios, instalações, equipamentos, facilidades e serviços dos aeroportos, não abrangidos pelas tarifas aeroportuárias; incidem sobre os usuários dos mesmos.

$\S 1^{0}$ As utilizações previstas neste artigo serão objeto de contrato, negociado entre as partes, no qual o preço de arrendamento não poderá ser inferior ao preço específico estabelecido.

$\S 2^{\circ}$ - Os contratos de utilização estabelecerão cláusulas de reajustamento dos preços específicos.

Art. 12 A utilização de áreas essenciais destinadas aos serviços das empresas de transporte aéreo ou dos proprietários ou exploradores de aeronaves, terá como retribuição o pagamento do preço específico referido neste Decreto.

$\S 1^{\circ}$ Para efeito deste artigo, entendem-se como áreas essenciais as destinadas à instalação de serviços próprios de apoio às operações aéreas em curso nos aeroportos e necessárias para:

(...)

e) comissaria, telecomunicações e meteorologia, quando de uso próprio; (grifos nossos) 
Por sua vez, para regulamentar a matéria, após a inovação legislativa, foram editadas três portarias: a Portaria Interministerial $n^{\circ}$ 24/MD/SAC, de 4 de janeiro de 2012, que dispõe sobre a provisão e a remuneração dos serviços de navegação aérea; a Portaria do Comando da Aeronáutica $\mathrm{n}^{\circ}$ 2/GC5, de 5 de janeiro de 2012, que dispõe sobre a recomposição dos valores tarifários em decorrência da extinção do adicional tarifário incidente sobre a tarifa de Uso das Comunicações e dos Auxílios à navegação Aérea (TAN) e sobre a Tarifa de Uso das Comunicações e dos Auxílios-Radio e Visuais em Áreas de Terminal de Tráfego (TAT); e a Portaria DECEA $n^{\circ}$ 44/DGCEA, de 29 de março de 2012, que aprova a reedição da Instrução Geral relativa à sistemática dos preços referentes às tarifas de navegação aérea. $^{9}$

Em síntese, o sistema é composto por duas remunerações principais: a Tarifa de Uso das Comunicações e dos Auxílios à Navegação Aérea em Rota (TAN) e a Tarifa de Uso das Comunicações e dos Auxílios Rádio à Navegação Aérea (TAT). Essa segunda modalidade ainda se divide em Tarifa em Área de Controle de Aproximação (TAT APP) e em Área de Controle de Aeródromo (TAT ADR). As tarifas, que incidem sobre o proprietário da aeronave, tem por escopo remunerar (art. 10 da Instrução Geral): a) Serviços de Informação Aeronáutica (AIS); b) Gerenciamento de Tráfego Aéreo (ATM); c) Meteorologia (MET); d) Facilidades de Comunicações e Auxílios à Navegação Aérea (COM); e) Serviços de Busca e Salvamento (SAR); f) Serviços de Informações de Vôo de Aeródromo (AFIS); e g) Outros Serviços Auxiliares de Proteção ao Vôo.

A TAN remunera os serviços de apoio à segurança aérea fornecidos pelo Comando da Aeronáutica ou pela INFRAERO. Ela é estabelecida em função do suporte prestado nas regiões de informações de vôo e nas áreas de controle e de natureza de vôo doméstico ou internacional e compõe valor unitário que remunera os custos devidos pela utilização dos serviços, instalações, auxílios e facilidades de controle de tráfego aéreo prestados em rota a uma aeronave de fator peso igual a 1, no percurso de $1 \mathrm{~km}$ (art. $24 \mathrm{da}$ Instrução Geral)

${ }^{9}$ In: http://servicos.decea.gov.br/tarifas/index.cfm?i=legislacao, consultado em 4 de fevereiro de 2013. 
A TAT APP, por sua vez, refere-se às facilidades disponibilizadas serviços, instalações, auxílios - para controle de aproximação. Ela é mensurada pelo valor unitário que remunera os custos devidos pela utilização dos serviços, instalações, auxílios e facilidades prestados a uma aeronave de fator peso igual a 1, em sua operação de aproximação em área terminal de tráfego aéreo, quando em procedimento de subida de ou descida para um aeródromo classificado (art. 28 da Instrução Geral)

Finalmente, a TAT ADR tem relação com o apoio dado pelo controle de aeródromo ou os serviços de informações de vôo de aeródromo e compõese pelo valor unitário que remunera os custos devidos pela utilização dos serviços, instalações, auxílios e facilidades prestados a uma aeronave de fator peso igual a 1, em sua operação de pouso em ou decolagem de um aeródromo classificado (art. 31 da Instrução Geral).

Em relação aos valores de cobrança, a rigor são estabelecidos por Portaria do DECEA, variando conforme o peso da aeronave, localidade e distância percorrida, quando esses fatores têm relação com a tarifa.

Feitas as devidas considerações sobre a questão tarifária, importante, por derradeiro sobre esse tema, lembrar que sobre esse serviço ainda pesa a contribuição ao Fundo de Universalização dos Serviços de Telecomunicações, por força do disposto no art. $6^{\circ}$, III e IV da Lei n ${ }^{\circ} 9.998$, de 17 de agosto de 2000, bem como a Taxa de Fiscalização de Funcionamento (TFF), conforme o art. $2^{\circ}, f \mathrm{c} / \mathrm{c}$ art. $6^{\circ}, \S 2^{\circ}$ e art. $3^{\circ}, a$, da Lei $\mathrm{n}^{\circ}$ 5.070, de 7 de julho de 1966.

\section{Expansão da infraestrutura de telecomunicações aeronáuticas: universalização}

Posto o cenário das telecomunicações aeronáuticas, resta a missão de voltar à discussão da expansão da malha para a universalização do serviço. Isso significa dizer, como asseveramos por premissa, que a ampliação do serviço de transporte aéreo depende da universalização dos serviços de telecomunicações aeronáuticas, que viabilizam a navegação aérea, o que se considera insumo essencial daquela atividade.

Como acima já mencionado, a cobertura de telecomunicações do território brasileiro não parece ser um óbice. Ilustra a figura 6 abaixo: 


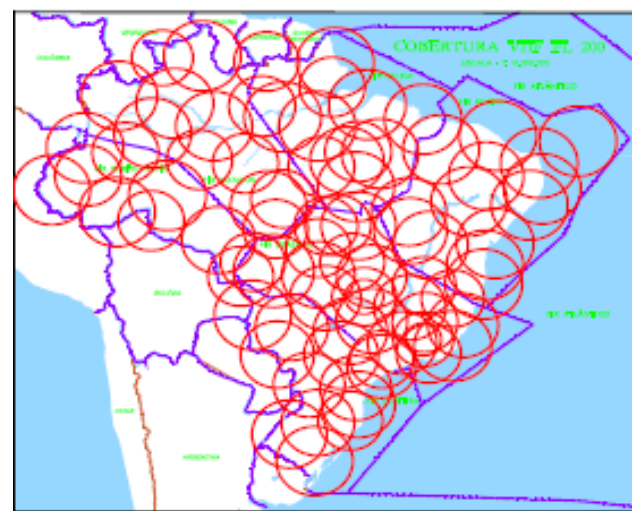

Figura 6 - Cobertura do Serviço Móvel Aeronáutico (Ministério da Defesa, 2010)

Contudo, com o aumento do tráfego, em vista da política de fomento aos vôos regionais e aeroportos, será requerido uma ampliação na quantidade de serviços de telecomunicações aeronáuticas. Essa tônica somente se resolverá com uma política de outorga massificada e direcionada para o transporte aéreo que se espera ampliar.

Assim, vale trazer a tona o debate sobre a infraestrutura das telecomunicações aeronáuticas, que em grande parte divide-se entre o DECEA e a INFRAERO. Enfatiza o DECEA, em seu sítio, sobre o tema:

Compõem a infraestrutura de telecomunicações aeronáuticas do DECEA: equipamentos de telefonia; equipamentos de comunicação via rádio, satélite e fibras ópticas; roteadores e redes de computadores; canais de comunicação alugados junto a concessionárias de telecomunicações e mais um universo de recursos espalhados por todo 0 território nacional, inclusive nas localidades mais remotas.

De seu lado da estrutura, informa a INFRAERO:

O serviço de telecomunicações da Infraero conta com modernos equipamentos e visa implantar e desenvolver bons padrões técnicos e operacionais. Para isso, a consolidação com a infra-estrutura de informática é fundamental. 0 objetivo é trabalhar com soluções convergentes, como a rede de comunicação voz/dados/imagens. Desta maneira, a empresa e seus clientes podem contar com instrumentos ágeis para suprir 0 intercâmbio de informações através da ampla rede de 
telecomunicações que interliga e abrange os aeroportos sob sua administração.

Fato que deve se ressaltar é que a tecnologia hoje utilizada nos serviços de telecomunicações aeronáuticas não atende aos requisitos de atualidade que esse tipo de serviço exige. Essencial a transcrição de estudo conduzido em 2006, no âmbito do Centro de Instrução e Adaptação da Aeronáutica (Cunha et al.), que traça um perfil de nosso sistema:

A infra-estrutura de navegação aérea atual está apoiada em meios de telecomunicações e de navegação instalados no solo, com alcance óptico, ou seja, com aberturas limitadas pela curvatura da Terra, que não possibilitam a sua aplicação homogênea no globo terrestre; além disso, a carência de auxílios à navegação aérea e de meios de telecomunicações é agravada por dificuldades econômicas por parte significativa dos países.

A efetividade dos serviços é, ainda, afetada pelo emprego de comunicações orais entre piloto e controlador, o que constitui fator de ineficiência, podendo ocorrer ambigüidade na comunicação e, em certos casos, afetar a segurança das operações aéreas.

A manutenção da concepção atual acarretaria crescentes congestionamentos do espaço aéreo nos próximos vinte anos, mesmo com o maciço investimento de recursos pelos países envolvidos, começando pelas regiões mais desenvolvidas, cujos reflexos imediatos nas demais regiões ocasionarão efeitos danosos para a indústria de transporte aéreo e inimagináveis prejuízos à economia e à sociedade mundial.

Com efeito, vale questionar se a necessária ampliação na quantidade de serviços de telecomunicações poderá se dar de maneira segura pelo DECEA e pela INFRAERO ou se seria necessário a abertura de amplo plano de outorgas que viabilize o atendimento de mais usuários por esse serviço. Diante dos indícios de omissão perante o conceito de serviço público adequado, estabelecido pelo art. $6^{\circ}$ da Lei $n^{\circ} 8.987 / 95$, em relação à universalidade e atualidade, mister se fazer a discussão quanto à natureza e modalidades de delegação desse serviço, como alternativa privada à prestação do serviço pelos órgãos da administração direta e indireta. $\mathrm{O}$ debate também se justifica diante da tendência de outorga da infraestrutura aeronáutica e aeroportuária, inaugurada pelas concessões de aeroportos. 
Nesse contexto, merece ainda atenção a temática de outorga conjunta, visto que as telecomunicações aeronáuticas atrelam-se às facilidades oferecidas pelo aeroporto, como acima vislumbrado.

\section{Outorga das infraestruturas aeronáuticas de telecomunicações}

Considerando o exposto no tópico sobre a natureza jurídica das telecomunicações aeronáuticas, firmou-se, com foco no SMA, que os serviços destinados ao transporte aéreo regular constituem-se em serviço de interesse coletivo. Por isso, tais serviços devem ser outorgados por concessão ou permissão e o transporte aéreo privado denota serviço de interesse restrito, submetido à delegação por autorização. Dada essa matriz inicial, importante conceber o modelo de despublicização que deveria ser aplicado a cada caso.

Insta salientar que, em princípio, para tais infraestruturas aeronáuticas, não se vislumbra a utilização do mecanismo da permissão, visto que este seria mais direcionado a serviços públicos formalizados mediante contrato de adesão, que não é o caso. De fato, cada unidade de telecomunicação aeronáutica tem peculiaridades, que, da sua complexidade, podem requerer contrato personalizado. Dessa forma, descarta-se a outorga de serviços de interesse coletivo por permissão, salvo se tratar de mera delegação da prestação, sem a responsabilidade pela infraestrutura requerida, que não se tem por plano abordar.

Passada as considerações iniciais, há que se questionar qual seria o objeto da outorga, levando em conta as infraestruturas cabíveis para o caso: Estação de Telecomunicações Aeronáuticas, Torre de Controle de Aeródromo, Controle de Aproximação, Centro de Controle de Área e Estações Prestadoras de Serviços de Telecomunicações e Tráfego Aéreo. Cabe perceber que o Centro de Controle de Área não estaria disponível para a delegação, pois se trata de estrutura estratégica de âmbito militar.

Expostas as possibilidades, deve-se questionar quais delas são primordialmente atrelados a serviços restritos e quais necessariamente operam serviços de interesse coletivo. Da gama apresentada, somente a EPTA, a TWR e a RADIO seriam passíveis de dedicar-se a serviços restritos. Isso porque podem ser apêndices de operações de aeroportos privados e de empresas de transporte aéreo particular, aqui considerado o 
serviço limitado. Dessa forma, pode-se concluir que cabe autorização, conjunta ou autônoma para as TWR e RADIO que atuarem em aeródromos, não destinatários do transporte aéreo público, bem como a EPTA voltada a apoiar operações de serviços aéreos privados, conforme capitulados nos arts. 177 a 179 do CBA.

De outra sorte, cabe concessão para as EPTA, TWR, RADIO, quando voltadas à navegação em aeródromos públicos e para o transporte aéreo público, nos termos do art. 175 c/c 180 a 221 do CBA e para APP em todos os casos, uma vez que em seu espectro de atuação, atualmente no Brasil, há de interagir com serviços aéreos públicos.

Interessante observar que no edital do Leilão $n^{\circ}$ 01/2011 para concessão para construção parcial, manutenção e exploração do Aeroporto Internacional de São Gonçalo do Amarante, constava como elemento da outorga a EPTA e a TWR, conforme obrigação estabelecida nas Disposições Relativas à Exploração da Estação Prestadora de Serviços de Telecomunicações e de Tráfego Aéreo, Anexo 9 do Contrato de Concessão:
1.1.1. A Concessionária deverá implantar uma Estação Prestadora de Serviços de Telecomunicações e Tráfego Aéreo (EPTA CAT "ESP"), comportando uma Torre de Controle, auxílios à navegação aérea e demais instalações especificadas no presente anexo, obedecendo ao estabelecido na ICA 63-10 (Estações Prestadoras de Serviços de Telecomunicações e de Tráfego Aéreo - EPTA), editada pelo DECEA.10

Adotando por outro caminho, no edital do Leilão $n^{\circ}$ 2/2011 para concessão para ampliação, manutenção e exploração dos aeroportos internacionais de Brasília, Campinas e Guarulhos, o Poder Concedente entendeu por bem não entregar os serviços de navegação aérea, destacando para si a obrigação de manutenção dessa atividade. Confira-se, nos termos do item 3.2 do Programa de Exploração do Aeroporto (PEA), Anexo 2 do Contrato de Concessão:

3.2. Não se inclui no objeto da Concessão a prestação dos serviços destinados a apoiar e garantir segurança à navegação aérea em área de tráfego aéreo do Aeroporto, sendo atribuição exclusiva do Poder Público, inclusive quando prestados por meio da Estação Prestadora de Serviços de Telecomunicações

${ }^{10} \mathrm{In}$ http://www2.anac.gov.br/asga/, visitado em 05.02.2013.

Revista de Direito, Estado e Telecomunicações, v. 5, n. 1, p. 65-106 (2013)

DOI: https://doi.org/10.26512/lstr.v5i1.21563 
Aeronáuticas e de Tráfego Aéreo (EPTA), a aquisição, instalação, operação e manutenção dos equipamentos relacionados aos seguintes serviços e facilidades:

3.2.1 Serviços de Informação Aeronáutica (AIS);

3.2.2 Gerenciamento de Tráfego Aéreo (ATM);

3.2.3 Meteorologia (MET);

3.2.4 Facilidades de Comunicações e Auxílios em Área Terminal de Tráfego Aéreo (COM);

3.2.5 Busca e Salvamento (SAR); e

3.2.6 Outros Serviços Auxiliares de Proteção ao Vôo, exceto os auxílios visuais (PAPI, VASIS, ALS, balizamento de pista de pouso e de taxi, luzes de eixo de pista de pouso e de eixo de pista de taxi, luzes de zona de toque, barras de parada, farol de aeródromo e biruta), que são de responsabilidade da Concessionária. ${ }^{11}$

A concessão das infraestruturas de telecomunicações aeronáuticas não atreladas aos aeródromos deve ser cercada de parâmetros adequados, inclusive com vistas a garantir os preceitos de universalidade e atualidade que ora se julgam essenciais, assim como os níveis de serviço que se quer obter. Nessa linha, chama a atenção o fato de a escolha do modelo de concessão representar decisão estratégica, mas imprevisível quanto a seus efeitos, como alertam Wald et al (2009):

É bom registrar que não há possibilidade de se afirmar, a priori, qual modelo de concessão é melhor ou mais vantajoso para a coletividade. Embora tenha um apelo popular, a decisão de reduzir ao máximo a tarifa de pedágio, não cobrando qualquer valor de outorga, pode implicar na distribuição dos custos da realização de outros investimentos em estradas entre todos os contribuintes, ao invés de atribuí-los apenas àqueles que diretamente se beneficiam desses recursos: os usuários.

Seguindo esses passos, há de se ter por pré-requisito a confecção de um plano de outorga e um plano geral de autorizações, nos moldes do que foi realizado no Decreto $\mathrm{n}^{\circ} 6.654$, de 20 de novembro de 2008, que possa dar

${ }^{11} \mathrm{In}$ h http://www2.anac.gov.br/GRU-VCP-BSB/, consultado em 5 de fevereiro de 2013. 
margem a um mapeamento, por estudos técnicos específicos, para a viabilidade dessas outorgas.

Tendo por pressuposto que a decisão acerca desse tema está adstrita a um posicionamento político da Administração Direta acerca da composição mínima da infraestrutura aeronáutica, pode-se verificar que eventual plano de outorgas de telecomunicações aeronáuticas deveria ser elaborado pela Secretaria de Aviação Civil da Presidência da República, que é a instância responsável pelo referido setor econômico. Por outro lado, o certame haveria de ser conduzido pela ANATEL, em conjunto com a ANAC, considerando que ambas tem claras atribuições sobre o instituto, como acima elencado.

Outro elemento que se permite aferir de pronto seria a modalidade da outorga: menor tarifa, na disciplina do art. 18-A da Lei $n^{\circ} 8.987$, de 13 de fevereiro de 1995. Isso para que a tarifa do serviço público seja estabelecida pela menor proposta, viabilizando custos mais módicos ao prestador de serviços, com vistas também à sua universalização.

\section{Conclusão}

O presente estudo se propôs a exercitar uma incursão sobre as telecomunicações aeronáuticas para a promoção de estudo jurídico sobre o instituto, que pudesse analisá-lo com vistas a entender seu funcionamento e justificar o dever do Estado em promover a delegação da infraestrutura necessária ao serviço para que se viabilize sua atualidade e universalização.

Nesse caminho foi possível apurar que as telecomunicações aeronáuticas podem representar tanto serviço de interesse coletivo, quando apóiam a execução de serviços aéreos públicos, quanto serviço de interesse restrito, quando se dedicam aos serviços aéreos privados, nos termos do Código Brasileiro de Aeronáutica.

Assumiu-se que, a despeito da cobertura de todo território nacional pela atual estrutura pública brasileiro, caso o Programa de Investimentos em Logística em Aeroportos seja bem sucedido, o tráfego aéreo poderá se ampliar em níveis maiores que a capacidade quantitativa de prestação do serviço, hoje exercido pela Infraero e, principalmente, pelo DECEA.

Dessa forma, a fim de que se garanta uma ampliação segura do transporte aéreo, faz-se necessário a outorga dos serviços de 
telecomunicações aeronáuticas, que sejam suficientes para dar vazão a essa potencial demanda que se delineia, partindo-se do pressuposto da expansão específica no Serviço Móvel Aeronáutico.

Destarte, consideradas as premissas constitucionais e legais que cercam as telecomunicações aeronáuticas, para que se possa garantir a expansão do serviço de transporte aéreo, seria essencial a universalização da capacidade da prestação e atualidade do serviço de telecomunicações aeronáuticas. Esta deverá se dar por concessão, no caso da outorga de infraestruturas de telecomunicações que prestem serviços para o transporte aéreo público e autorização, no caso das que forneçam apoio para os serviços aéreos privados.

\section{Bibliografia}

ALMEIDA, Tati et all (2009). Confecção de Carta Especial Aeronáutica de Pilotagem utilizando dados de sensoriamento: estudo de caso Carta Vila Sumuru, NB-20-Z-D. Anais XIV Simpósio Brasileiro de Sensoriamento Remoto, Natal, Brasil, 25-30 abril 2009, INPE, p. 1715-1722.

CAMPOS, Marcelo Brederodes (2008). A prestação dos serviços de telecomunicações e tráfego aéreo por entidades públicas ou privadas no SISCEAB tem um nome: EPTA. Aeroespaço - Informativo do Departamento de Controle do Espaço Aéreo - DECEA, Notícias - Ano 5 $n^{\circ} 31,12-14$.

ICAO - International Civil Aviation Organization (2003). Aeronautical Telecommunications: Communication Procedures including those with PANS status - Annex 10 to the Convention on International Civil Aviation, Montreal, Canada.

CUÉLLAR, Leila (2001). As Agências Reguladoras e seu Poder Normativo. Dialética, São Paulo.

CUNHA, Anderson Teixeira et al. A migração da Rede AFTN para um modelo mais robusto: ATN-AMHS. Disponível em http://www.ciaar.com.br/EM\%20FOCO/2006/com-2/AFTN.html\#sdfootnote4sym, consultado em 8 de janeiro de 2013.

MARQUES NETO, Floriano de Azevedo (2000). Direito das Telecomunicações. Direito Administrativo Econômico. Coord. Carlos Ari Sundfeld, Malheiros, São Paulo, p. 300-316. 
MINISTÉRIO DA DEFESA (2006). Critérios de Implantação de Órgãos ATS e de Auxílios à Navegação Aérea- ICA 63-18, Brasilia.

MINISTÉRIO DA DEFESA (2008). Manual de Telecomunicações do Comando da Aeronáutica - MCA 102-7, Brasilia.

MINISTÉRIO DA DEFESA (2009). Regras do Ar e Serviços de Tráfego Aéreo - MCA 102-12, Brasilia.

MINISTÉRIO DA DEFESA (2010). O Controle do Espaço Aéreo: principais atividades, Brasília.

MINISTÉRIO DA DEFESA (2011). Sistema de Pouso por Instrumentos (ILS) - ICA 100-16, Brasília.

MINISTÉRIO DA DEFESA (2011b). Regimento Interno do Departamento de Controle do Espaço Aéreo - RICA 20-1, Brasília.

MINISTÉRIO DA DEFESA (2012). Estações Prestadoras de Serviços de Telecomunicações e de Tráfego Aéreo - EPTA - ICA 63-10, Brasilia.

PACHECO, José da Silva (2006). Comentários ao Código Brasileiro de Aeronáutica. $4^{\text {a }}$. ed. rev. e atual., Forense, Rio de Janeiro.

PINTO, Victor Carvalho (2008). O Marco Regulatório da Aviação Civil: elementos para a reforma do Código Brasileiro de Aeronáutica. Textos para Discussão $n^{o}$ 42. Consultoria Legislativa do Senado - Coordenação de Estudos, Brasília. In: http://www.senado.gov.br/senado/conleg/textos_discussaol TD42-VictorCarvalhoPinto.pdf, consultado em 5 de janeiro de 2013.

SALADINO, Alejandra (2005). O fechamento da Panair do Brasil e a ascensão da VARIG. Revista Cantareira (UFF), v. 3, Rio de Janeiro, p. 120.

SALOMÃO FILHO, Calixto (2008). Regulação da Atividade Econômica: princípios e fundamento jurídicos. $2^{\mathrm{a}}$. ed. rev e atual. Malheiros, São Paulo.

SILVA, Flademir Candido \& Gonçalves, Emerson da Silveira (2008). Aeroportos Sociedade Anônima: uma projeção de abertura ao capital privado. $7^{o}$. Sitraer - Simpósio de Transporte Aéreo. 585-596 - Tr. 508. In: http://www.tgl.ufrj.br/viisitraer/pdf/508.pdf, consultado em 5 de janeiro de 2013.

SUNDFELD, Carlos Ari. A regulação de preços e tarifas dos serviços de telecomunicações. Direito Administrativo Econômico. Coord. Carlos Ari Sundfeld, Malheiros, São Paulo, p. 317-328. 
TRIGO, Luiz Gonzaga Godoi (2002). Viagem na Memória: Guia histórico das viagens e do turismo no Brasil. $2^{a}$. ed. rev e atual. SENAC São Paulo, São Paulo.

WALD, Arnoldo et al. Concessão de Rodovias e os Princípios da Supremacia do Interesse Público, da Modicidade Tarifária e do Equilíbrio Econômico Financeiro do Contrato. Contratos de Concessão de Rodovias: artigos, decisões e pareceres jurídicos. São Paulo, MP, 67-96. 
